\title{
The Roots of Religious Moderation in Indonesia: As-Singkili and Langgien's Works on Tolerance
}

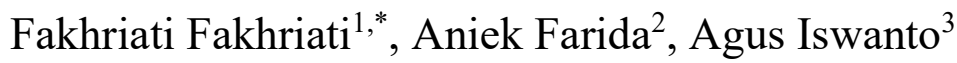

\author{
${ }^{1}$ National Research and Innovation Agency Republic of Indonesia, Indonesia \\ ${ }^{2}$ National Research and Innovation Agency Republic of Indonesia, Indonesia \\ ${ }^{3}$ National Research and Innovation Agency Republic of Indonesia, Indonesia \\ *Corresponding author.Email: fakhriati1406@gmail.com
}

\begin{abstract}
People could not practice religious moderation in full without understanding its historical roots. These roots entail an examination of actors involved in its development. In Indonesia, a vital actor is an ulama, who has taught and practiced moderation in this region's history. An indicator of this moderation is the existence of tolerance in society which harmony is maintained, and conflicts are minimized. This study examined the idea of tolerance developed, taught, and exemplified by As-Singkili and Langgien, two Aceh ulama who lived before Indonesia's independence. This study uses qualitative methods with a historical and anthropological approach. By scrutinizing their handwritten works, this study found that moderate attitude and action by prioritizing tolerance have always been the default positions of these ulama over time. Limited to the study of two Aceh ulama in the past, subsequent research should be conducted on other religious figures who cultivate these roots of tolerance. By doing so, present and future generations could strengthen their religious moderation, valuing tolerance to guide their attitude and actions.
\end{abstract}

Keywords: Religious moderation, tolerance, As-Singkili, Langgien, manuscript.

\section{INTRODUCTION}

The diversity of language, religion, and culture in Indonesian national life is at stake. If this diversity could strengthen social relations between different groups existing in the Indonesian state, the world would see Indonesia as an ideal type in diversity management. Conversely, if Indonesia could not manage this diversity, there might be adverse impacts to the world in the form of contagious social and racial conflicts [1], [2], [3], [4], [5]. Conflicts arising from differences in religious interpretations and truth claims possess tremendous destructive power, as religion and truth reside deep within a person's soul. Primarily, it is known that truth-interpretations and truth-claims are products of human effort to interpret the divine will and law of the Almighty God. They often result in differences as humans themselves live in different contexts and cultures [6], [7].

Tolerance of differences indicates a moderate religious attitude which could help alleviate any socioreligious conflict. The Indonesian government has announced religious moderation as a primary policy to develop a religious life. It has become an essential part of the Medium-Term National Development Plan (RPJMN) [8]. An encouragement of tolerance that affects religious adherents deeply could be found in religious teachings [9], [10], [11]. Tolerance has been internalized in the plural life of this region since a long time ago, one evidence being Sunan Kudus, who respected the rituals of the Hindus [12].

This study aims to discover the teachings of tolerance developed by As-Singkili [8], [13], [14] (who lived in the $17^{\text {th }}$ century) and Langgien [15], [16], [17] (who lived in the $19^{\text {th }}$ century). As Aceh ulama, they had bequeathed these teachings in their handwritten works in manuscript form. Therefore, the answers to three questions are sought in this study: (a) What is the idea of tolerance developed by these ulama during their lifetime?; (b) What are the foundations (philosophical and sociological) of their idea?; (c) What is the implication of their idea on character education today? The answers are hoped to show that tolerance is a way to strengthen national character and unity. As such, this study could be a reference and a record of history, which are helpful to resolve today's problems. 
Three arguments are presented in this study. First, the attitude of tolerance provides a capacity to develop a harmonious life and prevent potential conflict in national life. This harmony could permeate all aspects of life. Religious, linguistic, and cultural differences become parts of national diversity, a blessing towards co-existence. Second, religious tolerance has roots in social and cultural institutions, oral tradition, and written works of the past ulama. All these media should be maintained, preserved, and passed on to current and future generations so tolerance could become living value among them. Third, maintaining and preserving tolerance through contextualizing the ulama's works in the form of manuscripts could awaken the spirit of maintaining cultural heritage. This heritage could be a means to learn about the nation's ancestors' lives and the values they lived by to have a good life. Knowing the past would prepare the nation to face the future, with a better chance of improving the present.

\section{LITERATURE REVIEW}

\subsection{Tolerance in Religious Moderation}

Religious moderation, which acted as a social glue, has a long existence in the history of Nusantara [18]. It takes the form of maintaining balance, appreciation (tasamuh), egalitarian attitude, and discussions (musyawarah) among the people here, as well as accepting of, trying for and creating new ideas (being reformist, dynamic, and innovative) [1], [19]. In Islam, this moderation has always been taught by the prophets. Examples of tolerance abound in the Qur'an. Hundreds of verses encourage tolerance and discourage intolerance [20]. In addition, the prophets and their followers showed appreciation among themselves and others who led different lives [9].

Tolerance is an indicator of religious moderation. It means opening up a space for others to have different faiths, attitudes, and opinions. A tolerant stance would imply acceptance, respect, and positivity towards others [2], [21], [22]. Past ulama in this region and the world had developed a life of tolerance. A worthy example is Jalaluddin Rumi, who is praised all over the world for his humane, loving, and tolerant attitude towards others of different faiths [23], [24], [25]. Also, this region saw the examples of the teacher Marzuki from Betawi, Abdussamad al-Palimbani, and Kyai Rifai Salak [26], [27], [28].

\subsection{Ulama as Advocates of Moderation}

Ulama spread tolerance in this region through Islamic kingdoms' policy and as a propagation (da'wah) tool for the Muslim masses. The masses were taught to adapt their thinkings to prioritize dialogues and contextualize external influences from foreign
Muslim co-religionists and others having different faiths [6], [29], [18]. Tolerance among Indonesian was holistic and all-encompassing [30]. They had lived with Hindus side by side in a tolerant culture [31], [32].

The times of Islamic kingdoms also showed that these ulama respected differences and diversity. They preached that Islam taught its adherents to be polite to others of different beliefs. This message is following Pancasila values today. The lived practice of the ulama and the Islamic kingdoms influenced the development of Pancasila [33], [21]. Hamzah Fansuri, Syamsuddin as-Sumatrani, Ar-Raniry, and As-Singkili were among the ulama who successfully directed the Islamic kingdoms' policies towards a more tolerant society. These ulama were a vital and inseparable part of the kingdom in Aceh [34], [37].

\subsection{Contextualization of the Ulama's Thoughts}

Contextualization is an oft-used term in theology. In the Christian tradition, contextualization is an effort to channel, communicate and convey Biblical verses in a particular context. It also relates to church worship, music, songs, and ritual procedures. A contextualization of liturgy could be understood as a process to adapt, translate, channel, communicate, realize, and understand liturgical aspects in specific contexts [38], [39], [40], [41]. In Islamic tradition, efforts in contextualizing the Qur'an and Hadith have been conducted to ensure their message remains relevant to the needs of the age in all places and times. The relevance could be maintained as Islamic teachings have a high degree of flexibility. A manifestation of this could be observed in the ulama's thoughts on virtuous values, including tolerance. It is because their thoughts were always based on the Qur'an and Hadith [35], [36].

A contextualization of traditional values to suit current needs means dealing with change. For a society to continue to exist, there are four functional paradigms: adaptation, goal achievement, integration, and pattern maintenance [42]. Adaptation could mean the ability of society to change with the changing times. History has shown that many civilizations became extinct due to their inability to adapt. Hence, a contextualization of value systems that form the civilization's identity is a must for its continued existence [43], [44].

\section{METHODS}

This study focuses on two Aceh ulama manuscripts, As-Singkili and Langgien. The manuscripts showed that they seemed to have anticipated contemporary religious issues. The value of tolerance is needed for a holy living amidst 
diversity. It can also become a social glue for national unity. The thoughts of these two ulama could be considered as the roots for the development of religious moderation today. These thoughts, if practiced today, could prevent conflict and disunity. As such, they should be contextualized to today's issues, as would be done later in this paper.

A qualitative study with the historical and anthropological approach towards data collection and analysis, library study was conducted through available manuscripts and documents. A philological approach is not performed as the manuscripts' content is examined according to the study's objective. The data were then verified, processed, analyzed, and reconstructed to discover the idea of tolerance developed by As-Singkili and Langgien.

The manuscripts examined in this study are AsSingkili's monumental works. Namely, Tanbihul Masyi kept in Dayah Tanoh Abee Aceh, Umdatul Muhtajin kept in Museum Aceh with registered number 802 in Map 12, and Daqaiqul Huruf kept in Perpustakaan Negara Malaysia Cod. MS 1314. Langgien's works are examined, namely Dia'ul Wara and Dawa'ul Qulub, both collected privately by Ainal Mardhiah Pidie, Aceh, and Mi 'rajus Salikin kept in Perpustakaan Negara Malaysia Cod. MS 1044. The contexts before, during, and after they were written were also examined to uncover the backdrop to the tolerant stance developed by both ulama.

As-Singkili, his complete name is Abdurrauf ibn Ali al-Jawi al-Fansuri as-Singkili, lived in Fansur, Singkil, on the southwestern part of Aceh in the 17th century. One of those ulama who was close to the Aceh's kingdom was once requested to write a book titled Kifayatul Muhtajin by the Queen, Sultanah Safiyatuddin, and become a judge (qadi) (see Kifayatul Muhtajin). Two centuries after him, in the 19th century, Langgien (his complete name is Khatib Langgien) was born and resided in Teupin Raya, Pidie. The people of Aceh still use his works for village religious studies and in Aceh's traditional religious school (dayah). His books titled Dawa'ul Qulub and I'lamul Muttaqin were compiled by Shaykh Ismail bin Abdullah al-Asyi in the book Jam' $u$ Jawami'il Musannifat [45], known as Kitab Lapan in Aceh. This latter book contained the writings of eight past Aceh ulama, one of them being Langgien. Like Langgien's own books, Aceh also commonly uses this compilation for religious instructions. Both ulama were part of the Shattariyah tariqa, which continues to exist in Aceh [46], [47], [48], [49].

\section{RESULTS}

\subsection{The Idea of Tolerance of As-Singkili and Langgien}

The idea of tolerance developed by As-Singkili and Langgien could be accepted by both the elites and nonelites of Aceh. Based on the Qur'an and Hadith, they developed their idea for a diverse society, one in which its members had different cultures, viewpoints, and religions. They did not allow people to label others as unbelievers (kafir) as the labeling might result in conflicts. As such, they forbid this label to be uttered towards others.

Table 1 Encouragement to Avoid Utterance of Disbelievers towards Others

\begin{tabular}{|c|c|c|c|}
\hline \multicolumn{2}{|l|}{ As-Singkili's Writing } & \multicolumn{2}{|l|}{ Langgien's Writing } \\
\hline Text & Translation & Text & Translation \\
\hline $\begin{array}{l}\text { Wahfaz lisanaka 'anil gibati } \\
\text { wa takfiri fainna fihima } \\
\text { khataran 'aziman 'inda } \\
\text { rabbikal Kabir (As-Singkili, } \\
\text { n.d.: } 34 \text { ) }\end{array}$ & $\begin{array}{l}\text { Prevent your tongue from } \\
\text { gossiping and calling others } \\
\text { as disbelievers; both these } \\
\text { actions contain wrongs } \\
\text { which displeases the God } \\
\text { Almighty. }\end{array}$ & $\begin{array}{l}\text {...haram lah melihat kitab } \\
\text { ini oleh seorang yang tiada } \\
\text { ahli baginya karena } \\
\text { terkadang jadi ia ke dalam } \\
\text { bahaya kafir jika diamalkan } \\
\text { akan dia dan terkadang } \\
\text { mengkafir ia akan orang } \\
\text { lain (Langgien, n.d.: 30) }\end{array}$ & $\begin{array}{l}\text {...this book is unlawful to be } \\
\text { read by readers who are not } \\
\text { experts, as it might cause } \\
\text { unbelief when its contents } \\
\text { are practiced, and } \\
\text { sometimes its reader might } \\
\text { accuse others of unbelief'" }\end{array}$ \\
\hline $\begin{array}{l}\text {...dan tiadalah harus kita } \\
\text { mengkafirkan dia, karena } \\
\text { jikalau ada ia kafir, maka } \\
\text { tiadalah perkataan } \\
\text { dalamnya dan jika tiada ia } \\
\text { kafir, niscaya kembali kata } \\
\text { itu kepada diri kita (As- } \\
\text { Singkili, n.d: } 392 \text { ) }\end{array}$ & $\begin{array}{l}\text {... and we should not call } \\
\text { out a person of unbelief, as if } \\
\text { the person is indeed a } \\
\text { disbeliever, the person } \\
\text { should not have been called } \\
\text { out, and if the person is not a } \\
\text { disbeliever, the status of } \\
\text { unbelief would return to the } \\
\text { caller }\end{array}$ & $\begin{array}{l}\text {... Seperti Sabda Nabi Saw } \\
\text { Barangsiapa berkata akan } \\
\text { saudaranya dengan kafir } \\
\text { maka nyatalah saudaranya } \\
\text { itu kafir niscaya kembalilah } \\
\text { kafir itu kepada dirinya } \\
\text { (Langgien, n.d.: } 30)\end{array}$ & $\begin{array}{l}\text {.. Like the saying of the } \\
\text { Prophet. Whosoever calls } \\
\text { out his or her fellow as } \\
\text { disbeliever, the status of } \\
\text { disbeliever would be } \\
\text { possessed by either the } \\
\text { caller or the one being } \\
\text { called. }\end{array}$ \\
\hline
\end{tabular}


The writings in the table show that peace should be maintained by not calling others with labels of disbelievers. Every person and community has their views which should be appreciated and respected. The utterance and behavior of a person are keys to a peaceful life. The tongue should be prevented from calling others disbelievers, as feelings of resentment might arise, which may lead to conflicts.

The idea of tolerance developed by these two ulama is closely related to the Shattariyah tariqa they were a part of. As-Singkili initially introduced this tariqa to Nusantara in the Aceh region, where it still exists today [50], [48]. One practice of the tariqa is tolerance and an awareness of one's environment, even if the primary practice is on how to get closer to God. Langgien was also part of this tariqa in his time. We could find his idea of tolerance in his teachings to his students [51]. The principle of conflict resolution in tariqa life focused on teaching the tariqa masters to their students. These teachings of tolerance can be seen further in Tables 2 and 3.

On another level, both these ulama did not only teach tolerance to their students, but they also practiced it towards others who interacted with them. As a result, they were accepted at the level of Aceh kingdom and popular among their students and the society at large.
One proof of As-Singkili being respected by the kingdom is Queen Safiyatuddin to write Kifayatul Muhtajin, a book on how to practice the Shattariyah tariqa, and on the relationship between the Creator and the created. As-Singkili had many followers who later lived in various places, inside and outside Aceh. His tariqa teachings were propagated as far as Java by his student Abdul Muhyi Pamijahan [34], [50], [38]. Meanwhile, Langgien also made life in Pidie peaceful and comfortable. His karamah was visible in his lifetime and even after he passed away [46].

Table 2 shows that As-Singkili had at least two stances or principles in the community in which he lived: (1) to be firm when arguing about faith, yet protecting himself and his community from error by refraining from false accusations which may result in conflict; (2) to build a tolerant life by appreciating and helping others. These stances or principles could be discerned in his writing on the introductory page of his book Tanbihul Masyi.

Langgien also held the same tolerant stance. In addition, he cared for his community by teaching them the values of tolerance, as can be seen in the following table.

Table 2 As-Singkili's Idea of Tolerance

\begin{tabular}{|c|c|c|}
\hline Tolerance Elements & As-Singkili's Writings & Translation \\
\hline Determined & $\begin{array}{l}\text { fa akhāfu ayyunsama taqrīrur rajuli wa } \\
\text { i 'tiqāduhu ilā taqrīri wa i 'tiqādì hatta } \\
\text { yukaffirunì ba 'da wafātì (Al-Singkili, n.d.: 3) }\end{array}$ & $\begin{array}{l}\text { I am worried that such stipulation and } \\
\text { belief are ascribed to me such that } \\
\text { people after me accused me of } \\
\text { unbelief }\end{array}$ \\
\hline $\begin{array}{l}\text { Maintaining a good relationship } \\
\text { between people of different } \\
\text { faiths }\end{array}$ & $\begin{array}{l}\text { Mukmin yang bercampur dengan segala } \\
\text { manusia dan sabar ia atas siksa mereka itu } \\
\text { terlebih baik daripada mukmin yang tiada } \\
\text { bercampur dengan manusia (As-Singkili, } \\
\text { n.d.: 100) }\end{array}$ & $\begin{array}{l}\text { A faithful person interacts with } \\
\text { others. His patience in this interaction } \\
\text { makes him a better faithful person } \\
\text { than another who is not involved in } \\
\text { such interaction }\end{array}$ \\
\hline $\begin{array}{l}\text { Appreciating and helping each } \\
\text { other }\end{array}$ & $\begin{array}{l}\text { Mukmin itu cermin samanya mukmin dan } \\
\text { mukmin itu bersaudara samanya mukmin } \\
\text { barangmana bertemu ia dengan dia niscaya } \\
\text { dipadakannya pekerjaannya dan ditolonginya } \\
\text { akan dia pada ketika gaib dan ditegah segala } \\
\text { orang yangmengata-ngata ia dengan jahat } \\
\text { (As-Singkili, n.d.: 97) }\end{array}$ & $\begin{array}{l}\text { A faithful person is like a mirror to } \\
\text { another faithful person. They are } \\
\text { related, so when they meet, they } \\
\text { should help each other, and if they } \\
\text { don't, they should refrain from } \\
\text { uttering gossips about each other. }\end{array}$ \\
\hline Accepting differences readily & $\begin{array}{l}\text { Sifat mukmin itu lemah lembut lagi menerima } \\
\text { segala perangai yang baik tiada keras hati } \\
\text { lagi rahmah akan segala makhluk (As- } \\
\text { Singkili, n.d.: 102) }\end{array}$ & $\begin{array}{l}\text { The faithful are gentle in attitude, not } \\
\text { stubborn, and friendly to all creatures. }\end{array}$ \\
\hline
\end{tabular}


Table 3 Langgien's Idea of Tolerance

\begin{tabular}{|l|l|l|}
\hline Tolerance Elements & Langgien's Writings & Translation \\
\hline Caring and loving each other & $\begin{array}{l}\text { Dan setengah dari padanya mengasihi ia } \\
\text { akan segala manusia karena orang yang } \\
\text { kasih akan manusia kasih hak Ta'ala } \\
\text { (Langgien, n.d.:76) }\end{array}$ & $\begin{array}{l}\text {... and half of them love fellow } \\
\text { fumans because those who do so also } \\
\text { fulfill the right of God }\end{array}$ \\
\hline Not prejudiced towards others & $\begin{array}{l}\ldots \text { haram berbisik dua orang Padahal tiada } \\
\text { berbisik dengan orang lain jadi jahat } \\
\text { sangka orang lain akan keduanya } \\
\text { (Langgien, n.d.: 12) }\end{array}$ & $\begin{array}{l}\ldots \text { it is forbidden for two people to } \\
\text { whisper to each other in the presence } \\
\text { of others, arising their suspicion }\end{array}$ \\
\hline
\end{tabular}

Langgien attempted to find a middle way to live peacefully in the face of colonial power. He taught tolerance to his students and society. His stance was similar to As-Singkili. However, he was more careful in teaching spiritual knowledge. He hoped that those who received information and knowledge from him could use them carefully to prevent wrong attitudes and actions.

\subsection{Philosophy and Sociology of As-Singkili and Langgien's Idea of Tolerance (Contextualization)}

The idea of tolerance of As-Singkili and Langgien has philosophical and sociological contexts. Philosophically, tolerance is a foundational teaching of Islam. These ulama hold fast to and recite the Prophet's teaching in their writings. Sociologically, their background formed their moderate thoughts and behaviors and care of their communities. Peaceful life is the main thrust of their teachings. Also, both of them faced conflicts during their life, one between sufi ulama, the other between Acehnese and the colonizers.

The first conflict led to the struggle for positions in Aceh's kingdom. As-Singkili, like other sufi ulama, had to think hard on how to make peace in this situation. In the $17^{\text {th }}$ century, Aceh was led by Sultan Iskandar Muda and Sultan Iskandar Tsani. However, their treatment of the ulama was different. In the time of Sultan Iskandar Muda, local ulama were protected and prioritized in the kingdom. Their efforts to develop and spread knowledge in Aceh were more accessible. Such was not the case for Ar-Raniry, an Indian ulama based in Aceh who had to return to his country of origin as the Sultan did not accept his teaching. The political contestation between Ar-Raniry and Hamzah Fansuri led to As-Singkili taking his position [52]. AsSingkili was not influenced by the contestation, remaining sagacious about the conflict. As a sufi, he maintained his tolerance and appreciation towards others. He did not side with any party in the conflict, careful to maintain neutrality in thought and appearance [29].
The situation was different in the times of Langgien. The Aceh kingdom was weak in the 19th century when he lived. The ulama and uleebalang (local leader) were fighting against each other for state and religious control at a time when the Dutch were intensifying their attacks against Aceh. As an ulama, Langgien had to formulate a position based on wisdom to deal with the conflict. At the same time, conflicts were also re-occurring between sufi (spiritual-focused) and shar'i (legal-focused) ulama. In Teupin Raya, where Langgien lived, Teungku Id Gedung Huk proclaimed that he and his followers need no longer pray. They only needed to utter remembrance of God (zikr). His actions produced conflicts in society [53], [54]. Langgien intervened in this conflict by asking his followers to uphold tolerance in their interaction with and maintaining an appreciation of other members of society.

\subsection{The Implication of the Idea of Tolerance taught by As-Singkili and Langgien}

So strong is the value of tolerance upheld by both ulama, it could be deemed an ideology to them. The ulama worked hard to build a tolerant attitude among their tariqa followers and Aceh society in general. Among As-Singkili's teachings which today's generation could adopt, are courteousness, appreciating differences in character or religion, and withholding from calling others as disbelievers willy nilly. While among Langgien's teachings are: love one another, avoiding gossip, and appreciating each other's humanity.

As-Singkili's teachings seemed to have withstood the test of time. On the other hand, Langgien continued his idea of tolerance. Both these ulama taught unity amidst differences through religious moderation based on tolerance. They maintained that tolerance is vital in social interaction to preserve harmony and avoid conflict in community life.

In relation to national character, As-Singkili's explicit writings could be found in his books Tanbih 
al-Masyī and Mi'rajus Salikin. In contrast, Langgien's writings could be found in Dia'ul Wara' and Dawa'ul Qulub (see Table 1, 2, and 3). These are Sufi books containing teachings suitable for national character development. Both ulama taught balance and proportionality in maintaining relationships between humans and God (hablum minallah) and between humans themselves (hablum minannas). The balance and proportionality would manifest in positivity towards life. Conversely, ulama rejected negative and destructive attitudes, such as discrediting, disrespecting, insulting, and hurting others. These attitudes must be avoided as they cause a wedge and possibly disunity between people. So is the action of accusing others with different beliefs as disbelievers (takfiri). The system developed by these ulama could be seen as shown in Figure 1.

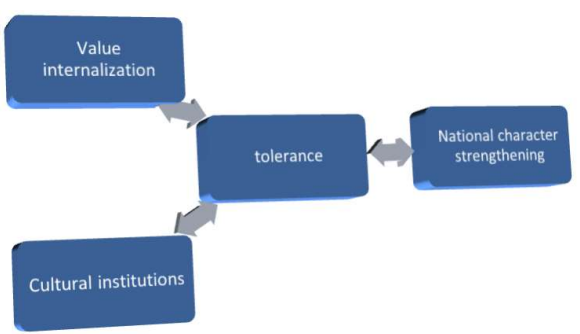

Figure 1 The system developed by the ulama

This system is indeed the roots of national character from the past. Such character is needed to protect local culture and wisdom in a nowheterogeneous society. A central part of the system is tolerance towards others of different backgrounds, religions, and cultures.

\section{DISCUSSION}

As-Singkili and Langgien laid the foundations for religious moderation based on tolerance. They advocated tolerance as a tool for Islamic propagation (da'wah) and teaching in the form of manuscripts, which remain accessible till today. The idea of tolerance they developed suits their society and other societies in this region of Nusantara [34]. In terms of time, this idea also suits today's global world, which requires flexible practices of goodness [35], [36]. Furthermore, the concept of adaptation with a dialogical approach makes this tolerance easier to contextualize [29], [42]. As such, there is a historical continuity in the idea of tolerance, proof that it may remain relevant in the future. History may not repeat itself, but its patterns may resurface from time to time [55], [56].

The idea of tolerance developed by both ulama could not escape the internal and external factors which influenced their thoughts. First, an internal factor was the conflict between sufi teachings of the ulama regarding the notion of wahdatul wujud. Some supported, while others rejected the notion [57], [58]. In the time of As-Singkili, Hamzah Fansuri's books were burned in front of Baitur Rahman mosque of Aceh due to the perceived deviant teachings of wahdatul wujud contained in them. During the time of Langgien, this conflict remained unresolved, albeit on a smaller scale at Teupin Raya, Pidie, where he lived. Second, an external factor was the ulama, who went for pilgrimage to Mecca then resided there. They maintained contact with Nusantara ulama and told them about the global colonization by non-Muslims. Studying in Mecca and Medina was an essential matter for Acehnese, to the point that a book was written on it titled Hikayat Makah Madinah. There is an important quote in this book:

Njang duek Sinan beroleh sa'adah njang minag surah celaka...[59].

Translation:

Those who stay there (Makkah and Madinah) would get blessings from God, and those who move from there would face unlucky fate...

These internal and external factors drove AsSingkili and Langgien to the idea and teaching of tolerance to their society. Tolerance and full support of Islam and the existing state were a yardstick for the ulama who performed pilgrimage and studied in Mecca [60].

Today, religious moderation is sorely needed in the face of Indonesia's multi-ethnic and multicultural character. This need should be fulfilled by developing a model of religious moderation with strong roots in the past. This model would benefit from the heritage contained in the classic works of the ulama. The model would inherit the same purpose in them: maintaining a peaceful and harmonious life, uniting people in society. As such, contextualization is essential. If ulama prioritized tolerance in $d a$ 'wah in the past, today, this should be continued and expanded into the educational sector in the form of the school curriculum and teaching materials. Education is a strategic medium in building a tolerant attitude towards differences [61], [62], [63].

This study showed that adapting past tolerance is vital for today's context. There should be continuity 
between a tolerant past and a present harmony across generations. Parents should teach tolerance to their kids [64], the kind that is suitable to the current diverse society. In Aceh, diversity is highly appreciated, thanks to the works of past ulama such as the two studied here. Immigrants from China, India, Arab, and Turkey continue to experience Aceh's tolerance. They were allowed to survive and live alongside the Acehnese. A proof is the existence of Kampung Turki (Turkish Village) in Banda Aceh. Indian groups could also be found in Sampang, Pidie Village. Arabs and Chinese are also living peacefully in Aceh [65], [66], [67]. Respecting, appreciating, and helping each other have become an inseparable part of being Acehnese.

\section{CONCLUSION}

This study has proved that religious moderation has roots in the heritage of past ulama through their written works. Tolerance has become a typical character in the past. As-Singkili and Langgien, two Aceh ulama who lived centuries apart, have lived a life of tolerance, taught their people to be tolerant, and written about tolerance in the face of difference and diversity. A careful reading of their writings, as has been done in this study, has shown that their thoughts remain relevant to contemporary issues faced by Indonesians today.

This study has also shown the importance of unearthing tolerance from the works of the past ulama. Their works could act as a bridge from the present to the future. Therefore, national vision and future nation-building should be based on a rigorous study of history. In other words, future documents should be a continuation of past documents.

This research has its limitation on manuscripts of As-Singkili and Langgien's idea and teaching of tolerance to their society. Therefore, other research should be conducted to examine other manuscripts written by other ulama in Nusantara, which contain good values, valid to strengthen citizens' patriotism. The history of Nusantara is littered with religious figures. Their works are a treasure trove of information waiting to be discovered. A variety of approaches could be taken to study their works, following their expertise and the research objective.

The finding of this study implies practically that The ulama's teachings in the manuscripts can contextualize according to national needs throughout the ages. As a country rich in manuscripts, Indonesia has a bountiful heritage of written culture. Therefore, this heritage should develop a national identity with genuine and strong roots. Furthermore, the study and contextualization of manuscripts could strengthen faith in Islam and love for the country. Faith and love are parts of Indonesian national character. This character has been passed down from generation to generation, as shown in this paper.

\section{REFERENCES}

[1] A. Akhmadi, Moderasi Beragama dalam Keragaman Indonesia. Inovasi-Jurnal Diklat Keagamaan, 13(2) (2019) 45-55.

[2] A. Aziz, Akar Moderasi Beragama di Pesantren (Studi Kasus di Ma'had Aly Sukorejo Situbondo dalam Terbentuknya Nilai-Nilai Moderasi Beragama). Ar-Risalah: Media Keislaman, Pendidikan Dan Hukum Islam, 18(1), (2020) 142. https://doi.org/10.29062/arrisalah.v18i1.348

[3] W. Bloom, Personal Identity, National Identity and International Relations. Cambridge University Press, 1993.

[4] C. Camilleri, \& H. Malewska-Peyre. Socialization and Identity Strategies. In John W. Berry, Pierre R. Dasen, \& T. S. Saraswathi (Eds.), Handbook of Cross-cultural Psychology: Basic processes and Human Development (Vol. 2). Boston: Allyn and Bacon, 1996.

[5] J. R. Seul, Ours is the way of God: Religion, identity, and intergroup conflict. Journal of Peace Research, 36(5) (1999) 553-69. https://doi.org/10.1177/0022343399036005004

[6] T. P. K. Agama, Moderasi Beragama. Jakarta: Kementerian Agama, 2019.

[7] M. Q. Shihab, Wasathiyah Wawasan Islam tentang Moderasi Beragama. Ciputat: Lentera Hati, 2019.

[8] A. As-Singkili, (n.d.-a). Daqa'iqul Huruf. Manuscript kept in Perpustakaan Negara Malaysia.

[9] M. Elius, I. Khan, R. B. M. Nor, M. Y. Z. M. Yusoff, \& K. Noordin, Islam As A Religion of Tolerance and Dialogue: A Critical Appraisal. Journal for the Study of Religions and Ideologies, 18(52) (2019) 96-109.

[10] W. S. Green, The "What" and "Why" Religious Toleration: Some Question to be Considered. In Jacob Neusner \& Bruce Chilton (Eds.), Religious Tolerance in World Religions. United State: Templeton Foundation Press, 2008.

[11] M. R. Othman, Inculcating The Essence of 'Wasatiyyah' In Muslim Society: The State Promotion and Muslim Intelligentsia Responses in Malaysia. Al-Sajarah, 19 (02) (2014). 
[12] N. Said, Jejak Perjuangan Sunan Kudus dalam Membangun Karakter Bangsa. Bandung: Brillian Media Utama, 2010.

[13] A. As-Singkili, (n.d.-b). Tanbihul Masyi. Manuscript kept in Dayah Tanoh Abee, Aceh.

[14] A. As-Singkili, (n.d.-c). 'Umdatul Muhtajin. Manuscript kept in Museum Aceh.

[15] K. Langgien, Dawa'ul Qulub. Manuscript Collected privately by Ainal Mardhiah Pidie, Aceh, $1238 \mathrm{AH}$.

[16] K. Langgien, Dia'ul Wara'. Manuscript Collected privately by Ainal Mardhiah Pidie, Aceh, $1238 \mathrm{AH}$.

[17] K. Langgien, (n.d.). Mi‘rajussalikin. Manuscript kept in Perpustakaan Negara Malaysia.

[18] N. Umar, Islam Nusantara: Jalan Panjang Moderasi Beragama di Indonesia, 2019.

[19] A. Nurdin, \& M. S. Naqqiyah, Model Moderasi Beragama Berbasis Pesantren Salaf. ISLAMICA: Jurnal Studi Keislaman, 14(1) (2019) 82-102. https://doi.org/10.15642/islamica.2019.14.1.82102

[20] Z. Misrawi, Al Quran Kitab Toleransi: Inklusivisme, Pluralisme, dan Multikulturalisme. Jakarta: Penerbit Fitrah, 2007.

[21] J. Menchik, Islam and Democracy in Indonesia: Tolerance without Liberalism. Cambridge University Press, 2016.

[22] M. Verkuyten, K. Yogeeswaran, \& L. Adelman, Intergroup Toleration and Its Implications for Culturally Diverse Societies. Social Issues and Policy Review, 13(1) (2019) 5-35. https://doi.org/10.1111/sipr.12051

[23] Z. Arif, Fihi Ma Fihi: Manifestasi Cinta dan Kebijaksanaan Rumi. Yogyakarta: Mueeza, 2018

[24] R. A. Nicholson, The Mathnawi of Jalauddin Rumi. Konya: Culture Publication, 2017.

[25] A. Salim, I. N. S. Lukmanulhakim, (Eds.) Moderasi Beragama Model Jalaluddin Rumi. Puslitbang Lektur, Khazanah Keagamaan, dan Manajemen Organisasi, 2020.

[26] Fakhriati. Moderasi Beragama dari Hati: Membumikan Karya dan Ajaran Abdussamad dalam Lokalitas Budaya. Pustaka Compass dan Puslitbang Lektur, Khazanah Keagamaan, dan Manajemen Organisasi, 2020.

[27] A. Firmanto, and Muchtar. Narasi Kebangsaan dan Moderasi Islam Syekh Ahmad Rifai. Pustaka
Compass dan Puslitbang Lektur, Khazanah Keagamaan, dan Manajemen Organisasi, 2020.

[28] A. Iswanto, Between Obedience and Social Tolerance: Reading Guru Marzuki Thought of Muara of Betawi on Kafir (1877-1934). Jurnal Masyarakat \& Budaya, 18(1) (2016) 33-46.

[29] O. Fathurahman, Abdurrauf Singkel. Tanbîh AlMâsyî Menyoal Wahdatul Wujud: Kasus Abdurrauf Singkel di Aceh Abad 17. Bandung: Mizan, 1999.

[30] M. C. Ricklefs, Sejarah Indonesia Modern. Yogyakarta: Gadjah Mada Univeristy Press, 1991.

[31] I. Burdah, The politics of Mataram Kingdom during the Reign of Sultan Agung. Journal of Indonesian Islam, 11(1) (2017). https://doi.org/10.15642/JIIS.2017.11.1.267306.

[32] M. Woodward, Islam in Java: Normative Piety and Mysticism in the Sultanate of Yogyakarta. University of Arizona Press, 1989. https://doi.org/10.2307/2803920

[33] L. Y. Fang, Sejarah Kesusastraan Melayu Klasik. Erlangga, 1993.

[34] A. Azra, Jaringan Ulama Timur Tengah dan Kepulauan Nusantara Abad XVII dan XVIII. Bandung: Mizan, 1995.

[35] Y. Ellethy, Introduction 1. In Islam, Context, Pluralism and Democracy, Routledge, 2020, pp. 15-33. https://doi.org/10.4324/9781315755533-

[36] E. Hamdeh, The role of the ulamā' in the thoughts of 'Abd al-fattāh abū ghudda. Muslim World, 107(3) (2017) 359-374. https://doi.org/10.1111/muwo.12199

[37] A. Hadi, Aceh: Sejarah, Budaya, dan Tradisi. Jakarta: Yayasan Obor Indonesia, 2010.

[38] E. Gunawan, Menuju Liturgi yang Kontekstual : Suatu Tinjauan terhadap Liturgi Gereja-Gereja Tionghoa Indonesia. Seminari Alkitab Asia Tenggara, 2014

[39] G. Kirchberger, \& J. M. P. Iman dan Transformasi Budaya. Ende; Nusa Indah, 1996.

[40] L. Y. Mandagi, Kontekstualisasi Ibadah sebagai Usaha Kontekstualisasi Teologi. Titian Emas, 2020(1) (2020) 59-65.

[41] J. C. Ratzinger, Truth and Tolerance: Christian Belief and World Religions. San Francisco: Ignatius Press, 2004. 
[42] T. Parsons, The Social System. Routledge, 2005.

[43] I. Abdullah, Konstruksi dan Reproduksi Kebudayaan. Yogyakarta: Pustaka Pelajar, 2015.

[44] D. Mulyana, Cultures and Communication: An Indonesian Scholar's Perspective. Bandung: PT Remaja Rosdakarya offset, 2012.

[45] S. I. A. Al-Asyi, (n.d.). Jam'u Jawami'il Musannifat. Semarang: Matba'ah Usaha Keluarga.

[46] Fakhriati. Refleksi Pengamalan Tasawuf di Aceh pada Abad ke-19M dalam Kitab Dia'ul Wara. Jurnal Lektur Keagamaan, 12(2), (2014) 319-44. https://doi.org/10.31291/JLK.V12I2.38

[47] A. Manan, The Influence of Tarekat Syattariyah Toward Political and Social Aspects in the Regency of Nagan Raya, Aceh-Indonesia. International Journal of Advanced Research, 5(7) (2017) 258-267.

https://doi.org/10.21474/ijar01/4714

[48] S. I. Shadiqin, Di Bawah Payung Habib: Sejarah, Ritual, Dan Politik Tarekat Syattariyah Di Pantai Barat Aceh. Substantia: Jurnal Ilmu-Ilmu Ushuluddin, 19(1) (2017) 75-98. https://doi.org/10.22373/SUBSTANTIA.V19I1. $\underline{2914}$

[49] K. Werner, The Syattariyah Sufi Brotherhood in Aceh. In Aceh: History, Politics, and Culture. Singapore: Institute of Southeast Asian Studies, 2010 .

[50] D. Carr, Narrative and the Real World: An Argument for Continuity. In Lewis P. Hincman and Sandra K. Hincman (Ed.), Memory, Identity, Community: The Idea of Narrative in the Human Science (pp. 7-25). Albany: State University of New York Press, 1997.

[51] H. Hermansyah, Mi 'rāj al-Sālikīn ilá Martabat al-Wāșilīn bi Jāh Sayyid al-'Ārifīn: Baqā'alțarīqah al-Shațārīyah fī Aceh Fatrat al-Isti'mār. Studia Islamika, 20(3) (2013).

[52] Y. Nazim, F. M. Kasim, The Role of Tasawwuf Ulama in the Governance of Aceh. International Journal of Academic Research in Business and Social Sciences, 8(10) (2018). https://doi.org/10.6007/ijarbss/v8-i10/4746

[53] O. S. Ishak, Dinamika Pemikiran Keagamaan di Aceh. Serambi Indonesia Jumat 15 Januari 1993, 1993.

[54] A. Poerwa, Tumbuhnya Agama baru di Indonesia. Sketsmasa Nomor 17, 1961.
[55] T. Parsons, The Social System. Routledge, 2005.

[56] D. Sylvester, Change and Continuity in History Teaching 1900-93. In, Hilary Bourdillon (Ed.). Teaching History. London: Routledge, 1999.

[57] R. Rasyad, H. Hermansyah, \& Z. Zulkhairi, Tanbīh Al-Māsyi Al-Mansūb Ilā Tarīq AlQusyasȳi: Analisis Uslub Bahasa Arab dalam Karya 'Abd Ar-Rauf As-Singkili. Adabiya, 18 (35) (2016).

[58] L. Samian, The Concept of Divinity in Malay Cosmology. MALIM: Jurnal Pengajian Umum Asia Tenggara (SEA Journal of General Studies), 20(0) (2019) 40-45. https://doi.org/10.17576/malim-2019-2001-04

[59] R. Idria, Makkah Madinah dalam Bahasa Aceh, 1723. In H. Chambert-Loir (Ed.), Naik Haji di Masa Silam: Tahun 1482-1890. Jakarta: Gramedia, 2013.

[60] C. Loir, Naik Haji di Masa Silam: Tahun 14821890, Vol. 1, Jakarta: Gramedia, 2013.

[61] H. W. Bachtiar, Masyarakat dan kebudayaan: Kumpulan Karangan untuk prof. Dr. Selo Soemardjan (1st ed.). Jakarta: Djambatan, 1988.

[62] J. W. F. Breman, Wertheim: A Sociological Chronicler of Revolutionary Change. Development and Change, 48(5) (2017) 113053. https://doi.org/10.1111/dech.12319

[63] J. L. Gillin, \& J. P. Gillin, Cultural Sociology a revision of an Introduction to Sociology. New York: The MacMillan Company, 1942.

[64] A. Florescu, Why Conservative Values Inherited from Previous Generations Will Continue to Shape Contemporary Identity? Journal for the Study of Religions and Ideologies, 19(56) (2020) 46-62.

[65] K. B. Ahmad, Acehnologi: Volume II. Banda Aceh: Bandar Publishing, 2017.

[66] M. Arifin \& K.B.M.K. Hambali, Islam dan Akulturasi Budaya Lokal di Aceh (Studi terhadap Ritual Rah Ulei di Kuburan dalam Masyarakat Pidie Aceh). Jurnal Ilmiah Islam Futura, 15(2), (2016)

251. https://doi.org/10.22373/jiif.v15i2.545

[67] A. R. Usman, Etnis Cina Perantauan di Aceh. Jakarta: Yayasan Obor Indonesia, 2009. 